\title{
CRUSTAL MOVEMENTS ALONG THE NW HELLENIC VOLCANIC ARC FROM DGPS MEASUREMENTS
}

\author{
Papageorgiou E., \\ University of Athens, Department of Geophysics and Geothermy, Zografou 15784, Greece, \\ epapageo@uoa.gr
}

\begin{abstract}
The north-western part of the Hellenic Volcanic Arc was studied by Differential GPS measurements in an attempt to investigate the regional deformation of the area. The GPS network involving stations in Athens, Aegina Island, Methana Peninsula and Soussaki was established in February 2006 and since then it was reoccupied twice. The GPS measurements were primarily referred to Worldfixed reference frame (ITRF2000) and then to Europe and Athens as well. The observed velocities for the overall three-year spanning period according to Athens station showed rates at the order of 7-10 mm/yr, while the directions of the displacements tend towards NNW to NNE. The results of the horizontal velocities with respect to Europe indicate rates of $S W$ directions, exhibiting higher magnitudes (25-26 $\pm 2 \mathrm{~mm} / \mathrm{yr})$ in the western and southern part of the Saronikos Gulf than in its central part $(20 \pm 7 \mathrm{~mm} / \mathrm{yr})$. The horizontal velocities with respect to ITRF2000 showed consistent SE directions with higher rates in Aegina $(12 \pm 7 \mathrm{~mm} / \mathrm{yr})$ than in Soussaki and Methana $(9 \pm 3 \mathrm{~mm} / \mathrm{yr})$. A kinematic interpretation based on velocity and strain rates is finally attempted on the basis of the regional tectonics in the Saronikos Gulf.
\end{abstract}

Key words: NW Volcanic Arc, Saronikos, GPS-velocity, tectonics, kinematics, strain.

\section{Introduction}

The NW Volcanic Arc has drawn our attention for research over the last 3 years due to its unique position, as being close to high populated areas, such as Attica, Corinth and Argolida. It is part of the Hellenic Volcanic Arc and has developed in the regional back-arc area of Saronikos Gulf, featuring a variety of volcanic fields. The referring volcanoes of Aegina, Methana and Soussaki (Fig. 1) manifested volcanic activity in Pliocene and Pleistocene times, while historical eruptions were recorded only in Methana (Strabo, Geographica). Submarine volcanic intrusions were also observed in the vicinity of NW Methana, defining the Pavsanias Volcano (Pavlakis et al., 1990). Tensional tectonics and sufficient crustal thickness are the major factors controlling the ascent of the magmas (Dietrich et al. 1988).

Several active faults have been recognized in the regional area of Saronikos (Makris et al., 2004). Yet, the seismicity which follows the main faulting zones is low (Drakatos et al., 2005). On the contrary, strong historical (Papadopoulos et al., 2000) and recent earthquakes (Makropoulos et al., 1989; Papazachos \& Papazachou, 1997) have occurred mainly in the western and northern boundaries of the basin, all associated with a roughly $\mathrm{N}-\mathrm{S}$ extensional tectonic regime.

The crustal deformation in Saronikos Gulf is considered to be fairly complex with block rotations, 


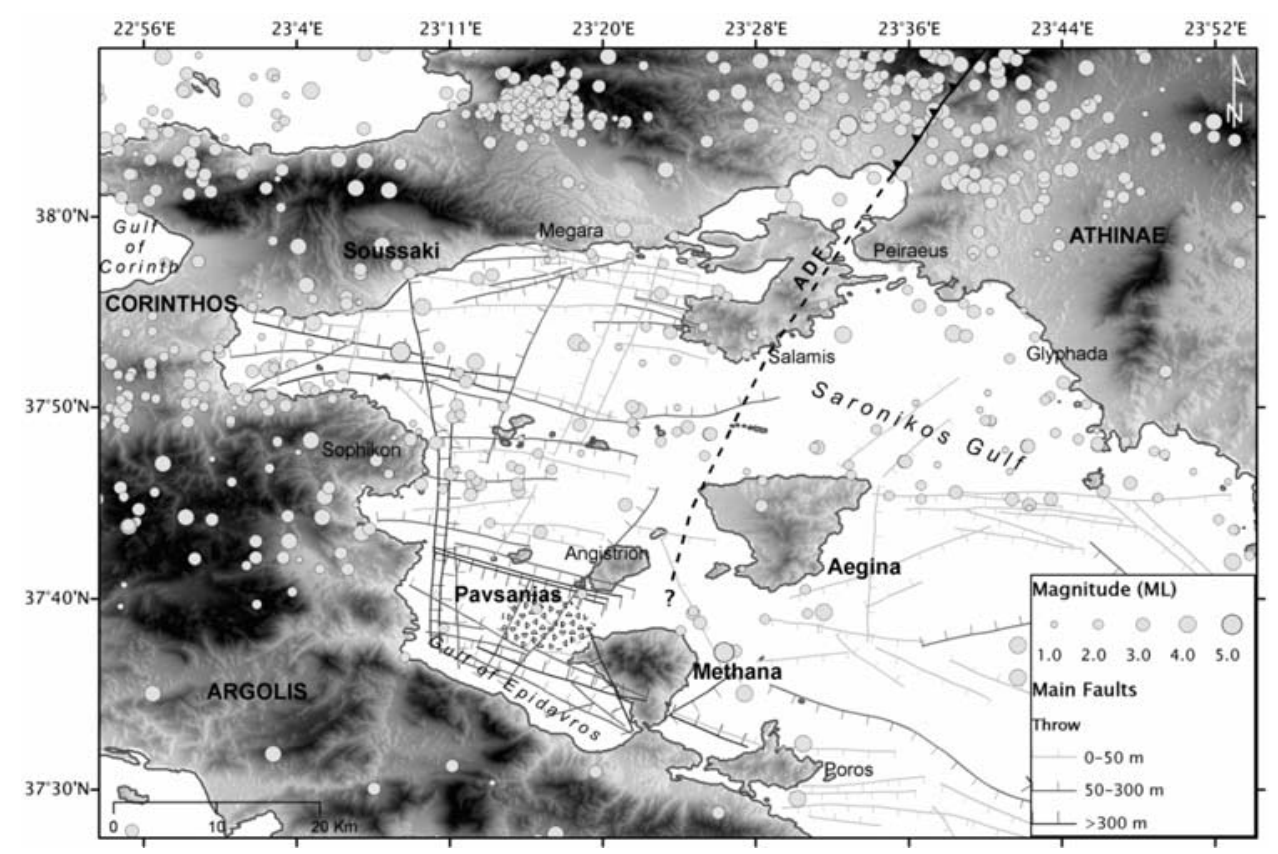

Fig. 1: Seismic activity (1950-2009, AUTH) and major tectonic faults in Saronikos Gulf (from Papanikolaou et al., 1988), at the NW stretch of the Volcanic Arc (Aegina-Methana-Soussaki). ADF: Attica Detachment Fault (Papanikolaou \& Royden 2007).

normal faulting and crustal fragmentation (Le Pichon \& Angelier 1979; McKenzie 1978; Rotstein 1985). Saronikos Gulf has rather affected by the neotectonic mechanisms acting between the West Hellenic subduction and the Anatolian westward drift. Extensive investigation on the regional deformation of Saronikos Gulf was attempted in this paper. GPS measurements were conducted from 2006 to 2009, in order to provide adequate information on the kinematic characteristics of the studied area. For that reason, a GPS network (SARNET) was established at the volcanic centers of Aegina, Methana and Soussaki as well as in Attica Peninsula. The detection of relative movements was finally allowed as the obtained time series of the measured points provide comparably high accuracy of a few $\mathrm{mm} / \mathrm{yr}$.

Therefore, the current kinematic field of crustal motion in Saronikos Gulf, based on repeated GPS observations, is analyzed in terms of velocity and strain rates. From these results a first assessment of the kinematic implications is given in light of tectonic and seismological data.

\section{Regional Tectonics}

The NW Volcanic Arc lies on Saronikos Gulf with the Pliocene volcanics of Aegina and the Pleistocene of Methana and Soussaki. The neotectonic basin of Saronikos exhibits a tensional regime with the formation of tectonic grabens by normal faulting (McKenzie 1978; Mercier 1979; Le Pichon \& Angelier 1979; Dewey \& Sengor 1979). In this view, it appears to have a rather complicated structure with different neotectonic styles and the presence of the recent volcanoes in the central part. A western and an eastern part are separated by a very shallow N-S platform at the islands of Methana, Aegina, Angistri and Salamis (Fig. 1). This boundary probably reflects the continuation of 


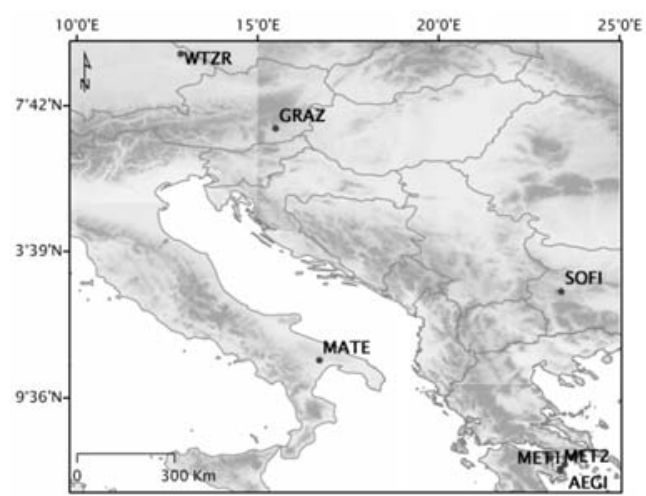

(a)

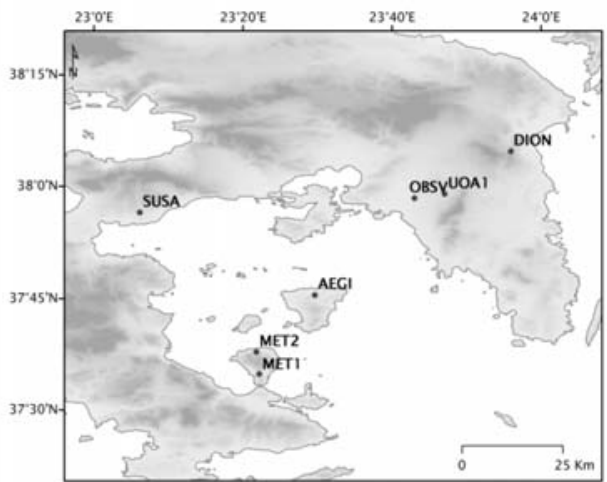

(b)

Fig. 2: (a) Locations of IGS and SARNET sites included in the GPS evaluation, (b) Locations of SARNET sites in detail.

the major NNE-SSW trending detachment fault that divides Attica Peninsula to the metamorphic units towards the east from the non-metamorphic units towards the west (Papanikolaou et al., 2009).

Each of the basins developed different fault patterns and displacements, sediment distribution (Papanikolaou et al., 1988) and seismicity (Makropoulos \& Burton, 1981; Bath, 1983). Due to the different structure, the western part is characterized by higher seismic activity than the eastern one. Moreover, the Western Saronikos Gulf is divided in a northern and a southern part by a well-defined E-W trending fault zone which seems to be the continuation of the Corinthiakos Gulf fault zone.

At the depth of $17 \mathrm{~km}$ the velocity increases considerably and the crustal thickness is restricted up to $20 \mathrm{~km}$. This noticeable low thickness in the region of Saronikos Gulf seems to be the result of the extensional stress field, which dominates the region, as well as of the emergence of mantle material along the NW volcanic arc, which clearly appears at the depth of $12 \mathrm{~km}$ (Drakatos et al., 2005).

\section{Microseismicity Setting}

In order to correlate the seismicity with active faulting in Saronikos Gulf, the seismic information mentioned in this paper is best described by Makris et al. (2004). The earthquake foci are located at two different depths, indicating the existence of two regional stress fields that dominate the Hellenides. The first cluster is concentrated at crustal levels and is related to extensional stresses of the upper crust, while the second concentration of hypocenters is observed at deeper sub-crustal levels. The deeper seismicity is associated with the NE-subduction of Ionian oceanic plate below Greece mainland (Leydecker, 1975; Makropoulos, 1978; Makris \& Roever, 1986).

Seismicity in Saronikos Gulf follows distinct tectonic features. Significant seismic activity is observed along the E-W-trending fault which divide Western Saronikos, and in between the Islands of Salamis and Aegina (Fig. 1). In addition, two clusters of epicenters are identified to the NE and east of Aegina, following the NE-SW and E-W orientated faulting structures respectively (Fig. 1). However, below Methana and Aegina volcanic centers deeper events have been registered, implying no evidence of seismic correlation with magmatic and hydrothermal processes (Makris et al., 2004). 
Table 1. Site names, coordinates and years of occupation of SARNET (5-8 days per campaing).

\begin{tabular}{|c|c|c|c|c|c|}
\hline $\begin{array}{c}\text { GPS } \\
\text { Station }\end{array}$ & Site & Long. $\left({ }^{\circ}\right)$ & Lat. $\left({ }^{\circ}\right)$ & Height (m) & Occupation (yr) \\
\hline AEGI & Aegina & 23,49 & 37,75 & 234 & $2006.14,2007.78,2008.55$ \\
\hline MET1 & Methana & 23,37 & 37,58 & 187 & $2006.14,2007.78,2008.55$ \\
\hline MET2 & Methana & 23,36 & 37,63 & 334 & $2006.14,2007.78,2008.55$ \\
\hline OBSV & $\begin{array}{c}\text { National Observa- } \\
\text { tory of Athens }\end{array}$ & 23,71 & 37,97 & 137 & $2006.14,2007.78,2008.55$ \\
\hline SUSA & Soussaki & 23,10 & 37,94 & 241 & $2006.14,2007.78,2008.55$ \\
\hline UOA1 & $\begin{array}{c}\text { University of } \\
\text { Athens }\end{array}$ & 23,78 & 37,98 & 306 & $2007.78,2008.55$ \\
\hline
\end{tabular}

Table 2. Site names, coordinates of IGS continuous stations included in GPS evaluation. DION located in Greece was also used as a reference station.

\begin{tabular}{|c|c|c|c|c|}
\hline $\begin{array}{c}\text { GPS } \\
\text { Station }\end{array}$ & Site & Long. $\left(^{(\mathbf{})}\right.$ & Lat. $\left({ }^{\mathbf{}}\right)$ & Height $(\mathbf{m})$ \\
\hline GRAZ & Graz & 15.4935 & 47.0671 & 538 \\
\hline MATE & Matera & 16.7045 & 40.6491 & 536 \\
\hline SOFI & Sofia & 23.3947 & 42.5561 & 1120 \\
\hline WTZR & Wettzell & 12.8789 & 49.1442 & 666 \\
\hline DION & Dionysos & 23.9326 & 38.0785 & 515 \\
\hline
\end{tabular}

\section{GPS Observations}

In order to reveal the kinematic field of the NW Volcanic Arc, Differential GPS measurements were carried out from 2006 to 2009. A GPS network (SARNET) was established for the first time in February of 2006 at the volcanoes of Saronikos (Aegina, Methana and Soussaki) and Attica Peninsula (Fig. 2). Stations were installed by emplacing benchmarks (bronze pins having head-diameter of $2.5 \mathrm{~cm}$ ) on the ground surface of carboniferous and volcanic rock formations. However, in the absence of bedrock in Soussaki the station was established on the concrete surface of an old construction. The network extending from Athens to the north, Soussaki to the west and Methana to the south was reoccupied two times since 2006, in October of 2007 and August of 2008. All DGPS measurements were made in the static mode using tripods above the benchmarks. Geodetic, dual frequency WILD receivers (SR299 and SR399) were employed for all measurements. Due to the long baselines of the network $(30-54 \mathrm{~km})$, all stations operated continuously for nearly a week with a sampling interval of $30 \mathrm{sec}$.

Stations names, epochs of measurements and approximate site coordinates are listed in Table 1.

To ensure a stable consistent reference frame, the data of Saronikos were evaluated together with those of IGS (International GPS Service) sites mainly located in Europe. For this process five IGS 

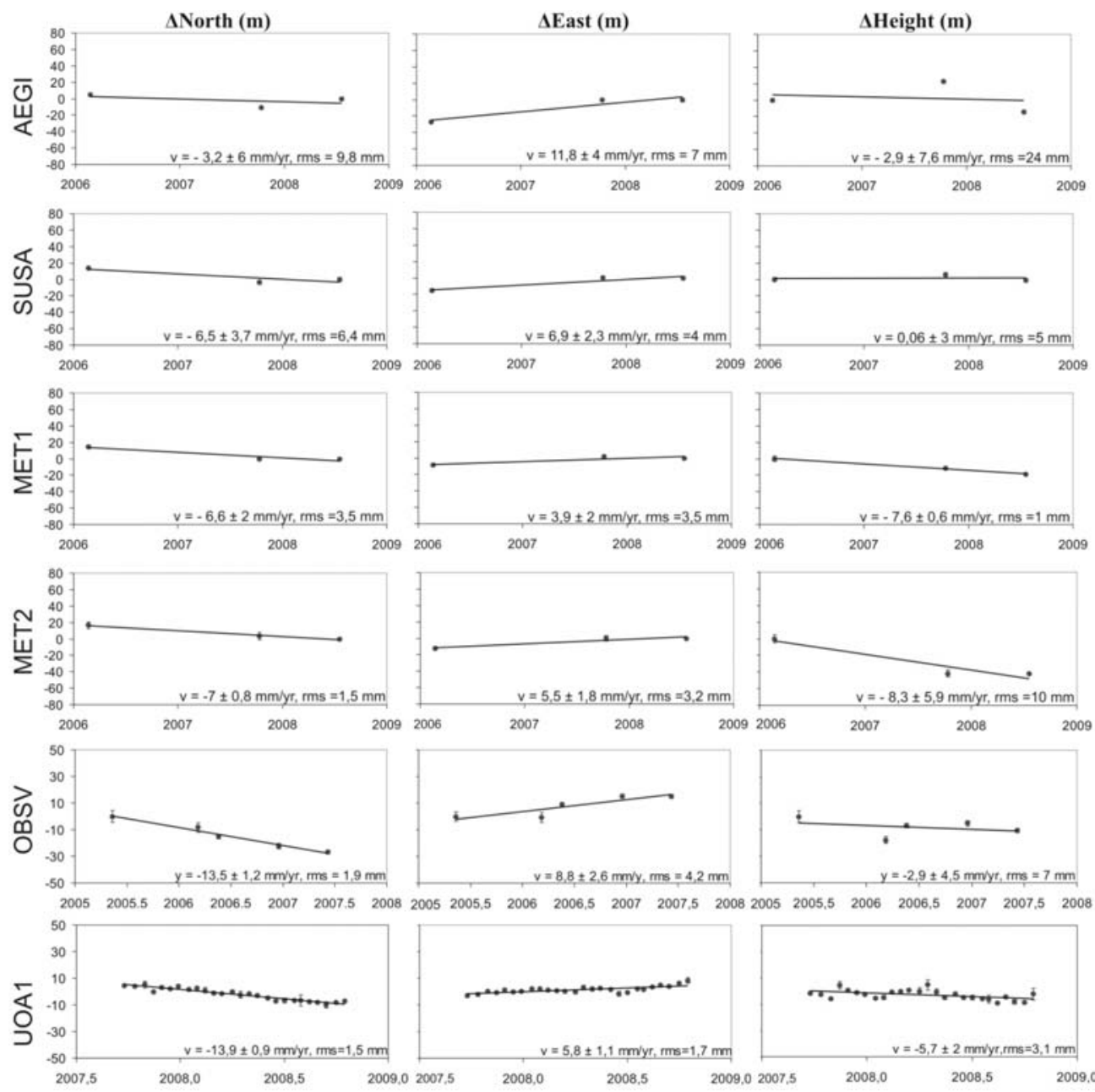

Fig. 3: GPS time series of campaign coordinates (ITRF2000) of Saronikos network.

sites were selected to define the reference frame. The locations of the included IGS sites are shown in Fig. 2. Station names, approximate coordinates are listed in Table 2. The observation data as well as site information (coordinates, receiver and antenna types) were downloaded directly from the IGS server.

The software used for the GPS processing was the Bernese GPS Software (BSW) version 4.2, of the Astronomical Institute - University of Berne AIUB (Beutler et al., 2001). An important point of the processing refers to the consistency of the reference frame. In order to obtain really consistent results, site coordinates and velocities, as well as satellite orbits and earth rotation parameters used for the processing were in the same reference frame ITRF2000 (Altamini et al., 2002; Boucher et al., 2004). The final results concerning the overall monitoring period of crustal motion in Saronikos Gulf, are presented below, in terms of velocities with accuracies of a few $\mathrm{mm} / \mathrm{yr}$. 


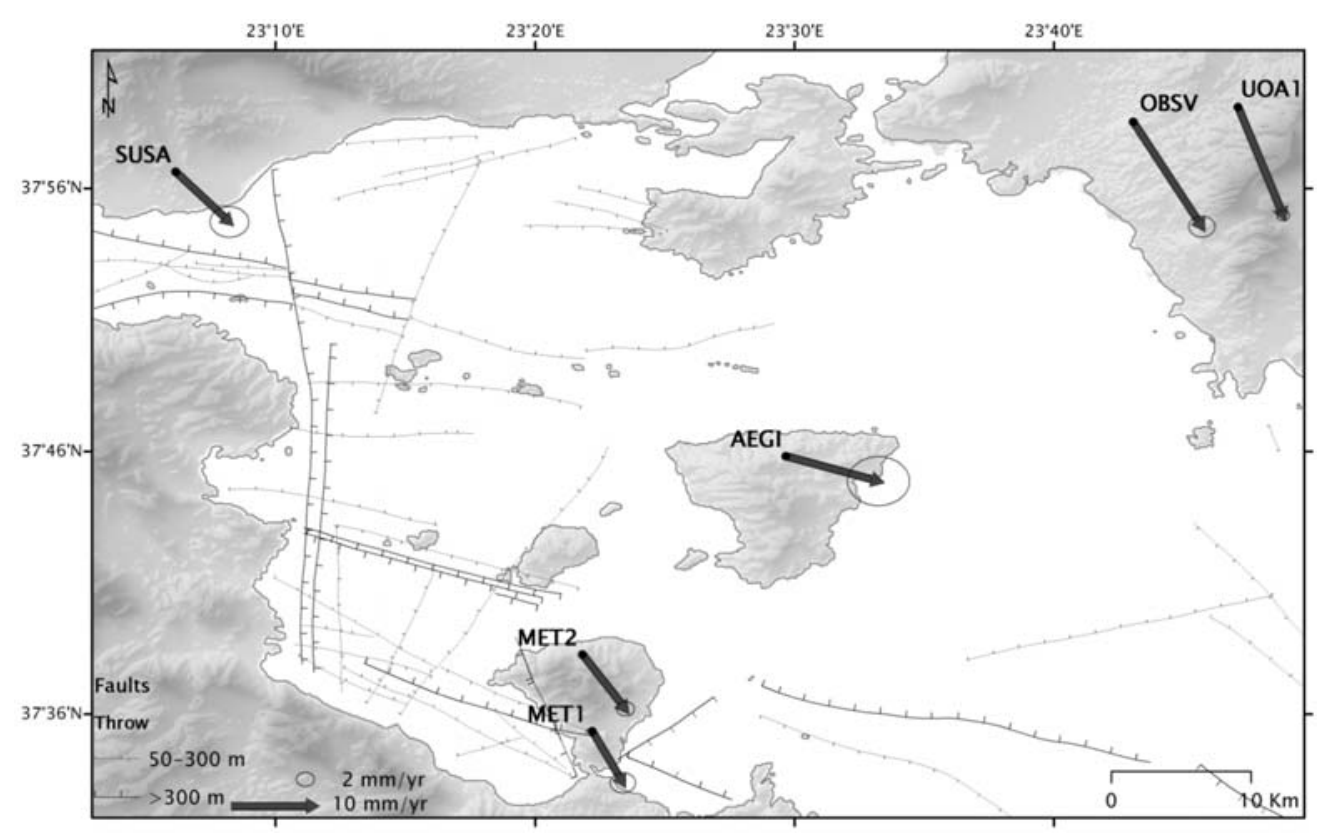

Fig. 4: Velocities with respect to ITRF2000, for the period 2006-2009.

Table 3. Velocities and corresponding precision with respect to World, Europe and Athens, for the period 2006-2009 (in mm/yr).

\begin{tabular}{|c|c|c|c|c|c|c|c|c|c|c|}
\hline & \multicolumn{2}{|c|}{ ITRF } & \multicolumn{2}{c|}{ ETRF } & \multicolumn{2}{c|}{ ATHENS } & \multicolumn{4}{|c|}{} \\
\hline GPS Station & $\mathbf{V}_{\mathrm{E}}$ & $\mathbf{V}_{\mathbf{N}}$ & $\mathbf{V}_{\mathrm{E}}$ & $\mathbf{V}_{\mathbf{N}}$ & $\mathbf{V}_{\mathrm{E}}$ & $\mathbf{V}_{\mathbf{N}}$ & $\mathbf{V}_{\mathrm{U}}$ & $\mathbf{\sigma}_{\mathrm{E}}$ & $\boldsymbol{\sigma}_{\mathrm{N}}$ & $\boldsymbol{\sigma}_{\mathrm{U}}$ \\
\hline AEGI & 11.8 & -3.2 & -11.7 & -15 & 3 & 10.3 & -2.9 & 4 & 6 & 7.6 \\
\hline SUSA & 6.9 & -6.5 & -16.7 & -18.3 & -1.9 & 7 & 0.1 & 2.3 & 3.7 & 3 \\
\hline MET1 & 3.9 & -6.6 & -19.7 & -18.4 & -4.9 & 6.8 & -7.6 & 2 & 2 & 0.6 \\
\hline MET2 & 5.5 & -7 & -18.1 & -18.8 & -3.3 & 6.5 & -8.3 & 1.8 & 0.8 & 5.9 \\
\hline OBSV & 8.8 & -13.5 & -14.8 & -25.3 & - & - & -2.9 & 2.6 & 1.2 & 4.5 \\
\hline UOA1 & 5.8 & -13.9 & -17.8 & -25.7 & -3 & -0.4 & -5.7 & 1.1 & 0.9 & 2 \\
\hline
\end{tabular}

The time series of campaign coordinates refer to ITRF2000 (International Terrestrial Reference Frame, ITRF). The velocity v of each site, as well as the corresponding coordinate precision (rms) was calculated by weighted linear regression over the campaign coordinates (Fig. 3). The rates of all sites are listed in Table 3, while Fig. 4 displays the horizontal velocities with respect to World. The velocity vectors indicate consistent direction towards the SE for the entirety of the stations. The highest velocity in Saronikos is observed at Aegina Volcano $(12.3 \pm 7 \mathrm{~mm} / \mathrm{yr})$, inasmuch as the lower rates at Soussaki $(9.4 \pm 4.4 \mathrm{~mm} / \mathrm{yr})$ and Methana $(8.9 \pm 2 \mathrm{~mm} / \mathrm{yr})$ volcanic areas. Athens sites display higher rates at the order of $16 \pm 3 \mathrm{~mm} / \mathrm{yr}$.

Velocities were also computed with respect to Europe, by adding the mean velocity of the European plate (Peter, 2000). The highest velocities are observed yet again in Athens (Table 3), while in Saronikos region, Methana and Soussaki represent higher rates than Aegina. MET1, MET2 and SUSA 


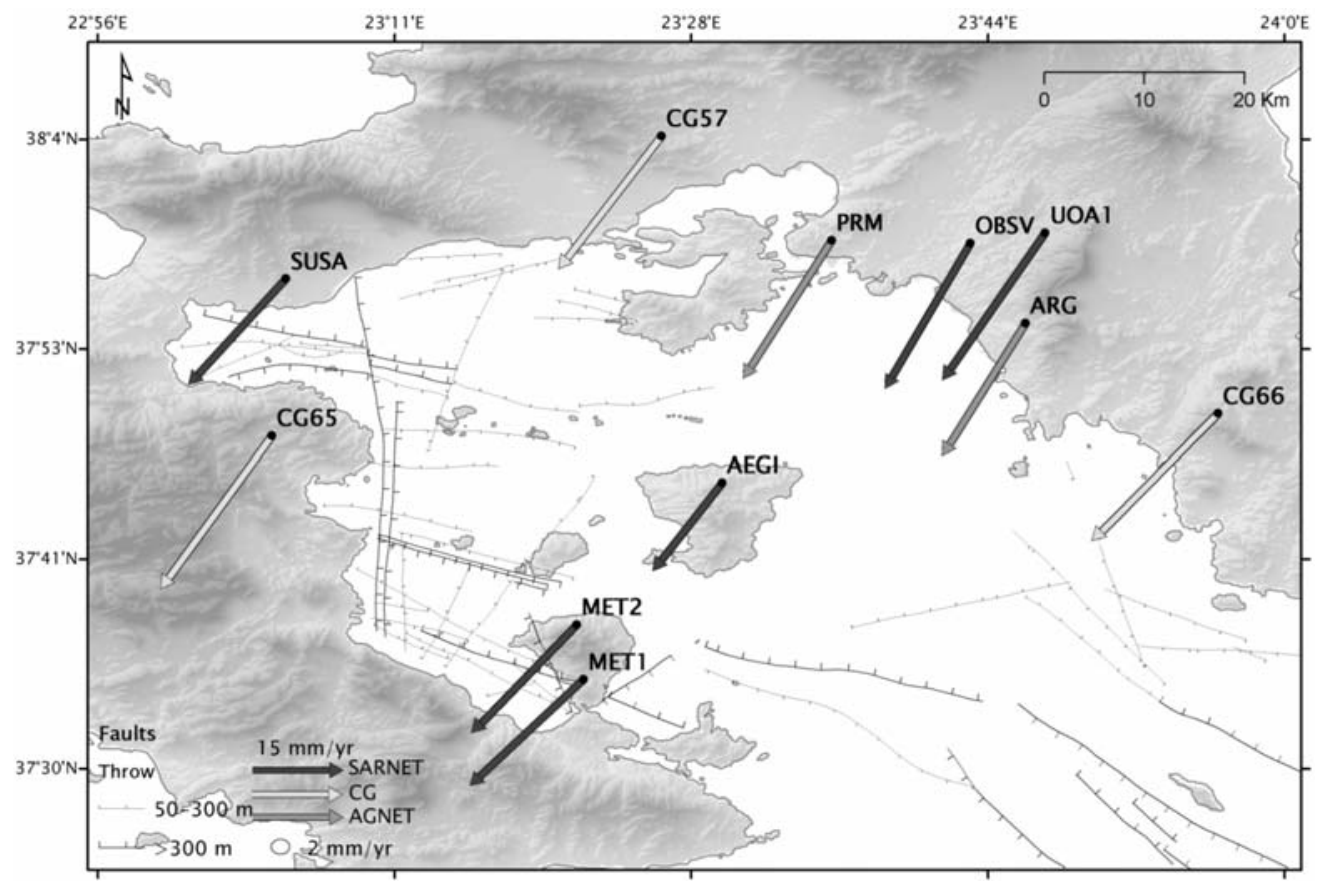

Fig. 5: Velocities with respect to Europe, for the period 2006-2009. Additional velocities used as input for the strain rate calculation are illustrated, belonging to nearby existing networks (CG: Clarke et al., 1998; AGNET: Foumelis, 2009).

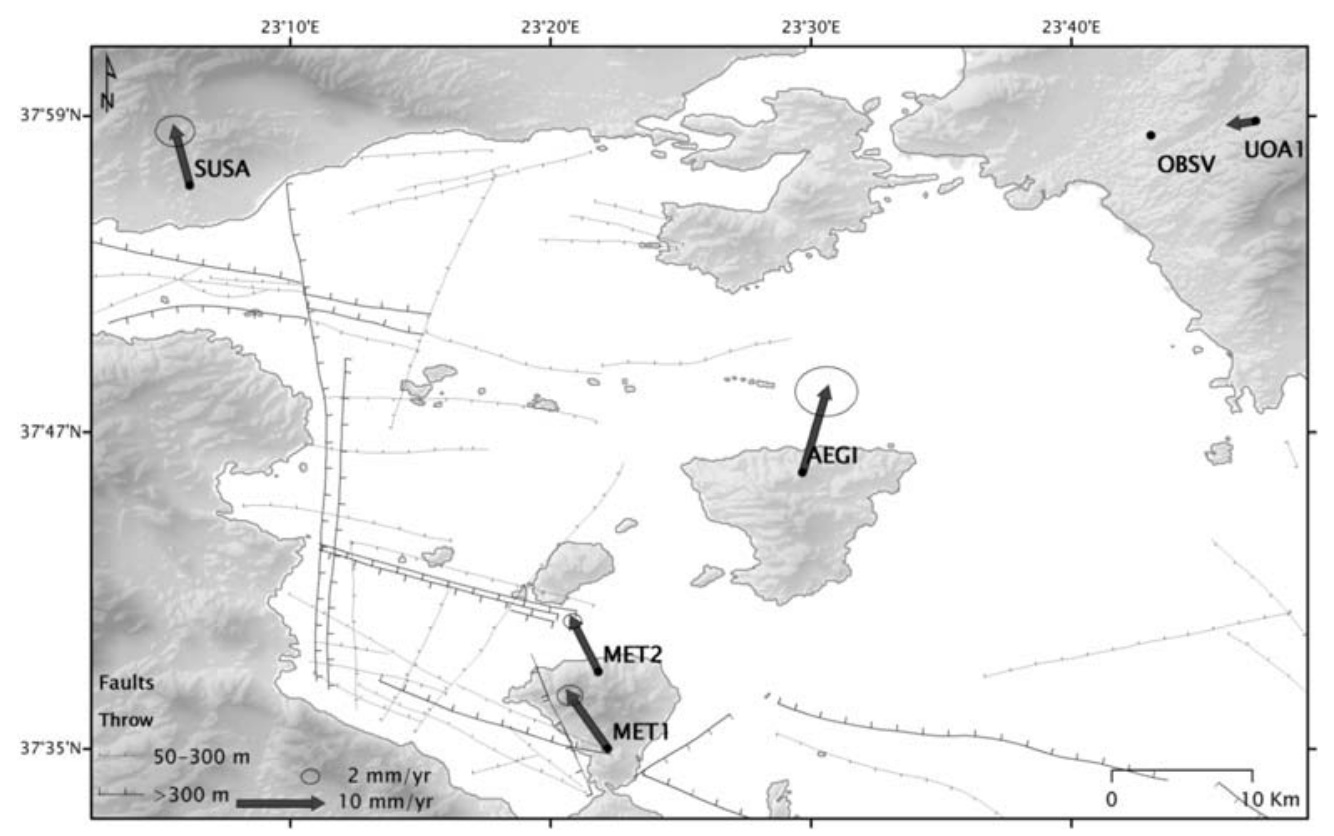

Fig. 6: Velocities with respect to Athens (OBSV), for the period 2006-2009. 
sites show almost equal velocities ranging between $25-27 \mathrm{~mm} / \mathrm{yr}$. AEGI site deviate from the rest Saronikos network by $6-8 \mathrm{~mm} / \mathrm{yr}$, indicating a different motion in the central part of the gulf. The horizontal velocities relative to Europe are shown in Fig. 5, where a general SW-ward direction of motion is observed for the whole network.

The velocities which were calculated with respect to Athens (OBSV site) underline the differentiation of AEGI site among the rest of the network. The southern (MET1-2 sites) and western (SUSA site) borders of the Saronikos Gulf show the same NW trending motion, in contrast to the central part (AEGI site) which exhibits different motion towards the NNE (Fig. 6). Additionally, MET2 and SUSA sites show equal rates of motion $(7.3 \mathrm{~mm} / \mathrm{yr})$, while AEGI site is moving with higher rates of approx $11 \mathrm{~mm} / \mathrm{yr}$ (Table 3).

The vertical motion of the network indicates a general subsidence both in Saronikos and Athens regions (Table 3). Southern Saronikos exhibits the highest subsidence with approximate rates $-8 \mathrm{~mm} / \mathrm{yr}$. AEGI site denote the same velocity with OBSV site $(-3 \pm 4.5 \mathrm{~mm} / \mathrm{yr})$, whereas at the same time SUSA site, bordering the Western Saronikos appears fairly stable with insignificant motion.

\section{Strain Rate Field}

The strain rate field was based on horizontal velocity rates shown in Fig. 5. For additional constraints, velocity rates belonging to adjacent networks were also included during the strain analysis. Hence, three sites (CG57, CG65 \& CG66) of the Central Greece (CG) network determined by Clarke et al. (1998), and two sites (PRM \& ARG) of the Athens local network (AGNET) determined by Foumelis (2009) were included. The azimuthal distribution of all sites at the periphery and inward the Saronikos Gulf was appropriate to ensure more accurate results due to the weighted distance between the stations, over and above the network centroid (centre of the mass) used as a reference point in the strain calculation.

In particular, the strain rate calculation was performed by grid_strain software package (Teza et al., 2008). It allowed the definition of one single deformation tensor over the whole studied area. Under the hypothesis of a uniform strain field condition, the velocity gradient components with the correspondingly errors were estimated by a least-squares adjustment (Shen \& Jackson, 2000). The data affected by larger uncertainties had a smaller effect on the strain computation. Finally, the principal axes of the strain tensor $\varepsilon_{\max }$ and $\varepsilon_{\min }$ were estimated, adapting three different scenarios: a) in the first case all sites were involved during the strain computation (Fig. 7), b) in the second case, the strain computation was held independently for western and eastern Saronikos selecting different baselines at each time; therefore, sites AEGI, PRM, SUSA, CG57-65 and MET1-2 were included for the western part-case, and accordingly sites OBSV, UOA1, ARG and CG66 for the eastern one (Fig. 8), and to end with case c) sites SUSA, AEGI and MET1-2 were taking into account for the strain calculation (Fig. 9).

The strain rate results which are presented in Figs. 7-9 mainly confirm the following:

- Along the whole Saronikos Gulf, compression (up to $209 \pm 22.6$ nstrain/yr) with almost N332 orientation is calculated, and an almost negligible extension along the perpendicular direction. As a result, a dilatation strain (rate) of -203 nstrain/yr and a total shear strain (rate) of 215 nstrain/yr were calculated (Fig. 7).

- Western Gulf shows extension (up to $102 \pm 54.8$ nstrain/yr) with N67 orientation and compression (up to $155 \pm 13.3 \mathrm{nstrain} / \mathrm{yr}$ ) with $337^{\circ}$ orientation. As a result, a dilatation strain (rate) of -53 nstrain/yr and a total shear strain (rate) of 257 nstrain/yr were calculated (Fig. 8). 


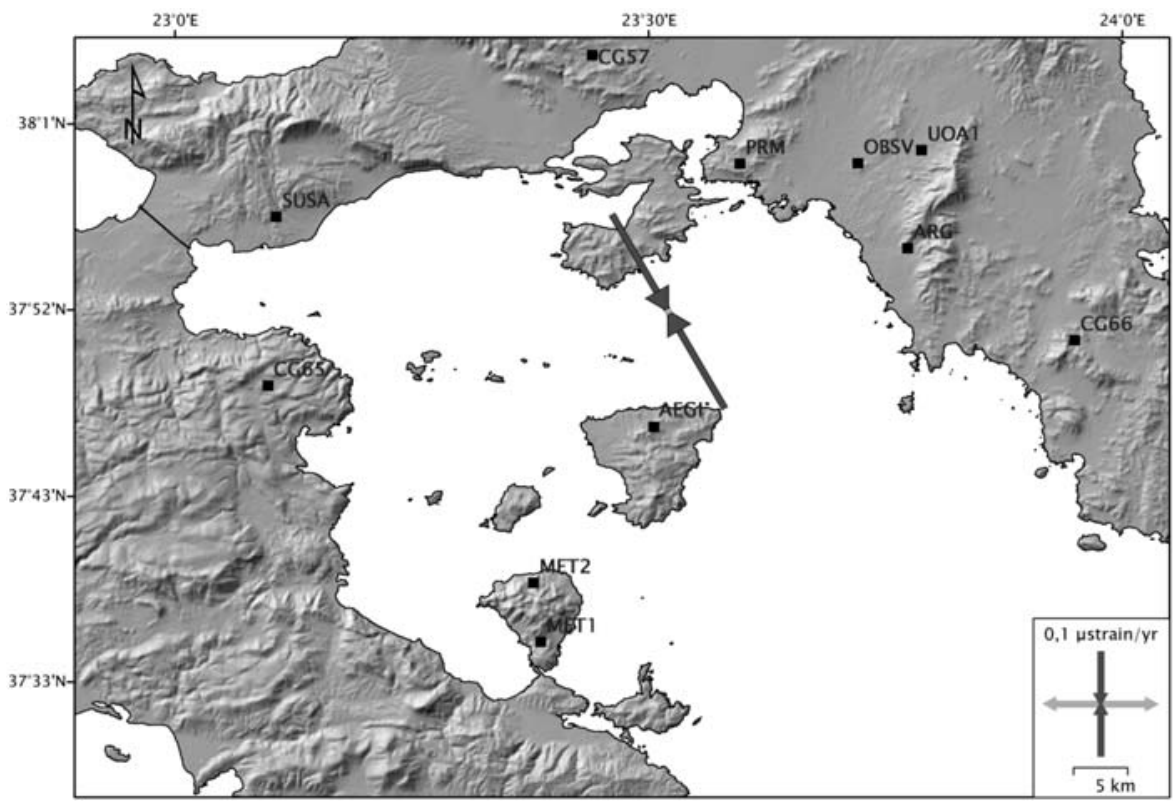

Fig. 7: Principle axes of the strain rate tensor calculated from the velocity field shown in Fig. 5, for Saronikos Gulf on the whole. Dark grey arrows indicate compression, light grey arrows extension.

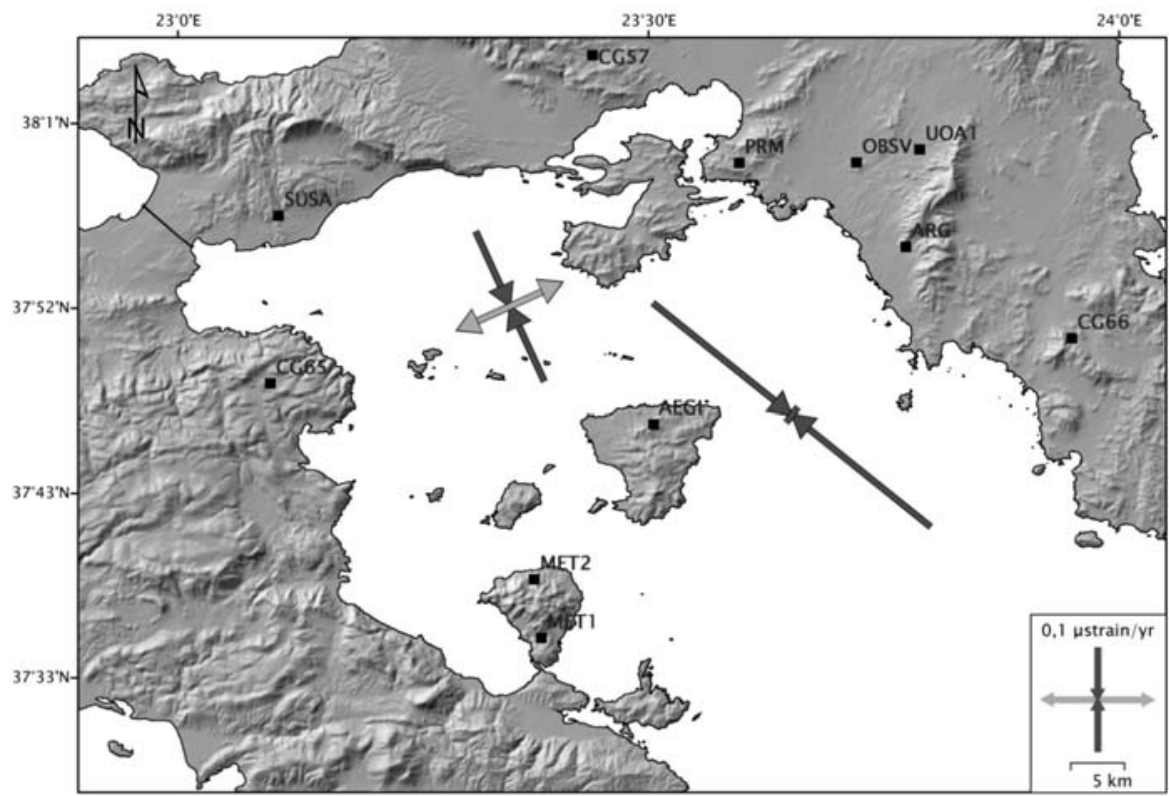

Fig. 8: Principle axes of the strain rate tensor calculated from the velocity field shown in Fig. 5, for the Western and Eastern Saronikos. Dark grey arrows indicate compression, light grey arrows extension. 


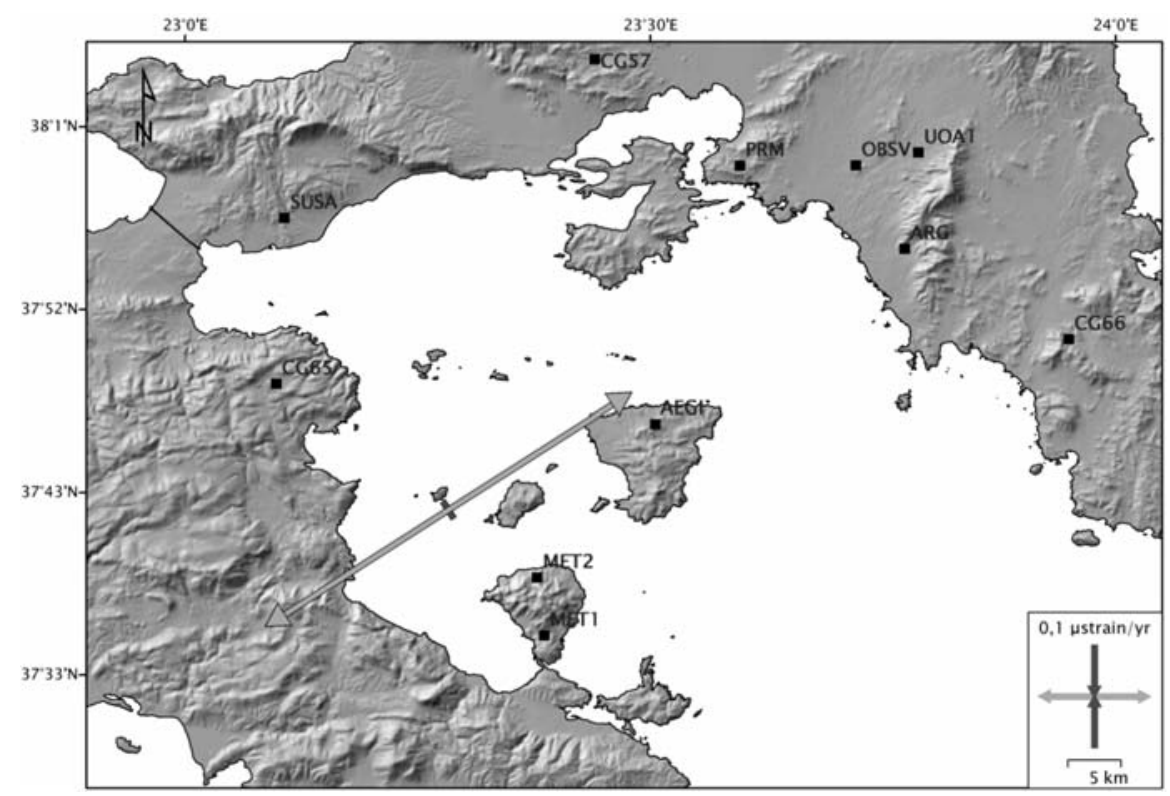

Fig. 9: Principle axes of the strain rate tensor calculated from the velocity field shown in Fig. 5, for the Western Saronikos (sites SUSA, AEGI, MET1, MET2). Dark grey arrows indicate compression, light grey arrows extension.

- Eastern Gulf shows compression (up to $330 \pm 3.4$ nstrain/yr) with N $311^{\circ}$ orientation (Fig. 8).

- Central to South Western Saronikos shows extension (up to $402 \pm 36$ nstrain/yr) with N59 orientation and secondary compression (up to $20 \pm 5 \mathrm{nstrain} / \mathrm{yr}$ ) along the perpendicular direction (Fig. 9).

The observed compression - extension indicates roughly the same orientation as it is shown in earlier studies (Hollenstein, 2006; Clarke et al. 1998). Still, comparison could be inferred only in the orientation and in the relative motion along the Saronikos Gulf and not to the deformation rates due to the different network spatial extent. Finally, the results indicate both extensional and compressional deformation field along the Saronikos Gulf, whereas higher rates of extension is observed at Western Saronikos, conversely to the compression occurring at Eastern Saronikos.

\section{Conclusions-Results}

The establishment of a local geodetic network around the Saronikos Gulf enabled the study of its kinematic characteristics based on GPS velocities and strain rate estimation. A first assessment of the kinematic constraints was held, taking into account the tectonic setting and the seismological information of the area.

The results of the DGPS analysis coincide with previous geological (Papanikolaou et al., 1988), seismological and tomographic (Drakatos et al., 2005) findings that divide Saronikos in two different basins. The western part, a region of active tectonic structures, extensional stress field and the presence of current volcanoes, includes MET1, MET2 and SUSA sites, howbeit presents a homogeneous kinematic pattern with consistent motion. The eastern part internally of the current volcanic arc, with volcanoes of Pliocene age, the more solid non-faulting structures and the minor 
deformation includes AEGI site, which indicates another trend of motion comparing with the rest of the network. The major detachment fault that cross Attica region to the north, probably continues until Southern Saronikos, differentiating Aegina from Methana and Soussaki volcanoes.

Previous geodetic studies in Saronikos Gulf have not been inferred by GPS measurements. Therefore, velocity results of the western volcanic arc described in this paper cannot be combined directly with other results concerning the same area. Yet, it could be accomplished with the most nearby existing networks (Foumelis, 2009). Finally, an agreement is achieved with the results concerning sites at the southern coast of Attica indicating the same rates of motion.

From the combined velocity field an estimation of the principal strain rates was accomplished. Western Saronikos reveals both extensional and compressional rates, while Eastern Saronikos is dominated by compression. The above mentioned differentiation of western and eastern gulf is also supported by the obtained strain field. The extension which was observed at the western gulf is probably affected by the westward opening of the Corinthiakos Gulf fault system, and its extension to Western Saronikos, retaining its approx E-W-strike, along several well-defined segments (Papanikolaou et al., 1988). The transition from the relative extension to the west gulf to the relative compression at the eastern gulf seems to be controlled so far by the major detachment fault identified to Attica Peninsula and its offshore continuation along the Saronikos Gulf (Papanikolaou et al., 2009). Furthermore, the significant number of faults to the west in contrast with the fewer faults to the east affects to a great extent the above mentioned transition. It may well be assumed that a fault fraction at Eastern Saronikos deform at least partially aseismically, when interpreting the observed strain rate. This could be the reason of the discrepancy between the geodetic results and the seismological findings. In the former both extensional and compressive strain fields are described whereas in the latter extensional tectonic field is reported for the upper crust. This inconsistency seems, to a certain extent, intricate and more extensive investigation is required. However, it is probably associated with the complex geodynamics of the region; extensional stresses due to deformation of the upper crust, as well as subduction of the oceanic Ionian slab below Hellenides (Makris et al., 2004).

The results are considered as a first preliminary step towards a better understanding of the complex present-day dynamics of the Saronikos Gulf. However, to account for the neo- and seismotectonic processes forming the major fault systems is a future work which remains under consideration.

\section{Acknowledgments}

This work was financed by (i) The European Union (75\%), (ii) The General Secretariat for Research \& Technology of The Ministry of Development of the Hellenic Republic (25\%), and (iii) Terramentor E.E.I.G. I would like to thank Professor Evangelos Lagios, Dr. Michael Foumelis for their constructive and critical comments and Dr. Vassileios Sakkas for the production of the time series of UOA1 site (see http://www.remsenslab.geol.uoa.gr/CGPS.html).

\section{References}

Altamini, Z., Sillard, P. and Boucher, C., 2002. ITRF2000: A new release of the International Terrestrial Reference Frame for earth science applications. J. Geophys. Res., 107(B10):2214, doi:10.1029/2001JB000561 .

Bath, M., 1983. The seismology of Greece. Tectonophysics 98, 165-180.

Beutler, G., Bock, H., Brockmann, E., Dach, R., Fridez, P., Gurtner, W., Hugentobler, U., Ineichen, D., Johnson, J., Mervart, L., Rothacher, M., Schaer, S., Springer, T. and Weber, R., 2001. Bernese GPS 
Software Version 4.2 edited by U. Hugentobler, Schaer, S. and Fridez P., Astronomical Institute, University of Berne, Switzerland.

Boucher, C., Altamini, Z., Sillard, P. and Feissel-Vernier, M., 2004. The ITRF2000. IERS Technical Note 31, Verlag des Bundesamts für Kartographie und Geodäsie, Frankfurt am Main.

Clarke, P.J., Davies, R.R., England, P.C., Parsons, B., Billiris, H., Paradissis, D., Veis, G., Cross, P.A., Denys, P.H.,Ashkenazi, V., Bingley, R., Kahle, H-G., Muller, M-V. and Briole, P., 1998. Crustal strain in central Greece from repeated GPS measurements in the interval 1989-1997. Geophys. J. Int., 135, 195- 214.

Dewey, J.F. and Sengor, C.A.M., 1979. Aegean and surrounding regions: complex multiplate and continuum tectonics in a convergent zone. Bull. Geol. Soc. Am., 90, 84- 92.

Dietrich, V.J., Mercolli, I. and Oberhänsli, R., 1988. Dazite, High-Alumina-Basalte und Andesite als Produkte Amphibol-dominierter Differentiation (Aegina und Methana, Aegäischer Inselbogen). Schweiz. Mineral. Petrogr. Mitt., 68, 21-39.

Drakatos, G., Karastathis, V., Makris, J., Papoulia, J. and Stavrakakis, G., 2005. 3D crustal structure in the neotectonic basin of the Gulf of Saronikos (Greece). Tectonophysics, 400, 55- 65 .

Hollenstein, C., 2006. GPS deformation field and geodynamic implications for the Hellenic plate boundary region, Ph.D Thesis, $359 \mathrm{pp}$.

Le Pichon, X. and Angelier, J., 1979. The Hellenic Arc and trench system: a key to the Neotectonic evolution of the Eastern Mediterranean area. Tectonophysics, 60, 1-42.

Makris J., Papoulia J., Ilinski D., Karastathis, V., 2004a. Crustal study of the Saronikos-Corinthiakos basins from wide aperture seismic data: intense crustal thinning below the Saronikos basin. X Conference of the Hellenic geological society, Thessaloniki, Greece. Abstracts.

Makropoulos, K. and Burton, P., 1981. A catalogue of seismicity in Greece and adjacent areas. Geophys. F. R. Astron. Soc., 65, 741-762.

Makropoulos, K., Drakopoulos, J., Latoussakis, J. 1989. A revised and extended earthquake catalog for Greece since 1900. Geophys. J. Int. 98, 391-394.

McKenzie, D.P., 1978. Active tectonics of the Alpine Himalayan Belt, the Aegean Sea and surrounding regions. Geophys. J.R. Astron. Soc., 55, 217-252.

Mercier, J.L., Sorel, D., Vergely, P., Simeakis, K., 1989. Extensional tectonic regimes in the Aegean basins during the Cenozoic. Basin Research, 2, 49-71.

Papadopoulos, G.A., Drakatos, G., Papanastassiou, D., Kalogeras, I., Stavrakakis, G., 2000. Preliminary results about the catastrophic earthquake of 7 September 1999 in Athens. Greece. Seismol. Res. Lett. $17,318-329$.

Papageorgiou, E., 2009. Surface Deformation Study for the Evaluation of Volcanic Hazard Assessment using Geophysical and Space Techniques: The Case of the Hellenic Volcanic Arc. Doctorate Thesis, University of Athens (GR).

Papanikolaou, I., Papanikolaou, D., Drakatos, G., 2009. Differentiation of the Fault and Seismicity Pattern on either side of the Major Detachment Fault in the Attica Peninsula and the Saronikos Gulf, Greece. Geophysical Research Abstracts, 11, EGU2009-9494, EGU General Assembly 2009.

Papazachos, B.C. and Papazachou, K., 1997. The Earthquakes of Greece.Zitti Publ., Thessaloniki, p. 304.

Pavlakis, P., Lykousis, V., Papanikolaou, D., Chronis, G., 1990. Discovery of a new submarine volcano in the Western Saronic Gulf: The Paphsanias Volcano. Bull. Geol. Soc. Greece, XXIV, 59-70.

Peter, Y., 2000. Present day crustal dynamics in the Adriatic-Aegean plate boundary zone inferred from continuous GPS measurements. Ph.D. Thesis, Zurich.

Rotstein, Y., 1985. Tectonics of the Aegean block: rotation, side arc collision on crustal extension, Tectono- 
physics, 117, 117-137.

Shen, Z.-K., Jackson, D.D., 2000. Optimal estimation of geodetic strain rates from GPS data. EOS Transactions of the American Geophysical Union 81, S406.

Strabo. Geographica, Lib. I, 3, 59.

Teza, G., Pesci, A., Galgaro, A., 2008. Grid_strain and grid_strain3: Software packages for strain field computation in 2D and 3D environments. Computers \& Geosciences 34, 1142-1153.

Foumelis, M., 2009. Surface Deformation Study of the Broader Area of Athens (GR) based on Differential GPS Measurements and Radar Interferometry. Doctorate Thesis, University of Athens (GR), 458 p. 